\title{
Inhibition of Tetraspanin Functions Impairs Human Papillomavirus and Cytomegalovirus Infections
}

\author{
Laura A. Fast ${ }^{1,+}{ }^{\oplus}$, Snježana Mikuličić ${ }^{1,+}$, Anna Fritzen ${ }^{1}$, Jonas Schwickert ${ }^{1}$, Fatima Boukhallouk ${ }^{2}$, \\ Daniel Hochdorfer ${ }^{3}$, Christian Sinzger $^{3}$, Henar Suarez $^{4,5}$, Peter N. Monk ${ }^{6}{ }^{1}$, María Yáñez-Mó ${ }^{4,5}$, \\ Diana Lieber ${ }^{3}$ and Luise Florin ${ }^{1, *(D)}$ \\ 1 Institute for Virology and Research Center for Immunotherapy (FZI), University Medical Center of the \\ Johannes Gutenberg University, 55122 Mainz, Germany; laura.fast@uni-mainz.de (L.A.F.); \\ snjezana.mikulicic@gmail.com (S.M.); fritzenaen@t-online.de (A.F.); jonas.schwickert@web.de (J.S.) \\ 2 Institute for Medical Microbiology and Hygiene, University Medical Center of the Johannes Gutenberg \\ University, 55122 Mainz, Germany; bouk@uni-mainz.de \\ 3 Institute of Virology, Ulm University Medical Center, 89081 Ulm, Germany; \\ danielhochdorfer@gmail.com (D.H.); Christian.Sinzger@uniklinik-ulm.de (C.S.); diana_lieber@gmx.de (D.L.) \\ 4 Departamento de Biología Molecular, UAM, 28049 Madrid, Spain; henar.suarez.montero@gmail.com (H.S.); \\ maria.yannez@uam.es (M.Y.-M.) \\ 5 Centro de Biología Molecular Severo Ochoa (CBM-SO), Instituto de Investigación Sanitaria Princesa (IIS-IP), \\ 28006 Madrid, Spain \\ 6 Department of Infection, Immunity and Cardiovascular Disease, School of Medicine and Biomedical Science, \\ University of Sheffield, Sheffield S10 2RX, England, UK; p.monk@sheffield.ac.uk \\ * Correspondence: lflorin@uni-mainz.de; Tel.: +49-6131-179083 \\ $+\quad$ L.A.F. and S.M. contributed equally to the manuscript.
}

Received: 4 September 2018; Accepted: 27 September 2018; Published: 2 October 2018

\begin{abstract}
Tetraspanins are suggested to regulate the composition of cell membrane components and control intracellular transport, which leaves them vulnerable to utilization by pathogens such as human papillomaviruses (HPV) and cytomegaloviruses (HCMV) to facilitate host cell entry and subsequent infection. In this study, by means of cellular depletion, the cluster of differentiation (CD) tetraspanins CD9, CD63, and CD151 were found to reduce HPV16 infection in HeLa cells by 50 to $80 \%$. Moreover, we tested recombinant proteins or peptides of specific tetraspanin domains on their effect on the most oncogenic HPV type, HPV16, and HCMV. We found that the C-terminal tails of CD63 and CD151 significantly inhibited infections of both HPV16 and HCMV. Although CD9 was newly identified as a key cellular factor for HPV16 infection, the recombinant CD9 C-terminal peptide had no effect on infection. Based on the determined half-maximal inhibitory concentration $\left(\mathrm{IC}_{50}\right)$, we classified CD63 and CD151 C-terminal peptides as moderate to potent inhibitors of HPV16 infection in HeLa and HaCaT cells, and in EA.hy926, HFF (human foreskin fibroblast) cells, and HEC-LTT (human endothelial cell-large T antigen and telomerase) cells for HCMV, respectively. These results indicate that HPV16 and HCMV share similar cellular requirements for their entry into host cells and reveal the necessity of the cytoplasmic CD151 and CD63 C-termini in virus infections. Furthermore, this highlights the suitability of these peptides for functional investigation of tetraspanin domains and as inhibitors of pathogen infections.
\end{abstract}

Keywords: human papillomavirus; HPV16; human cytomegalovirus; tetraspanin; virus entry; blocking peptide; $\mathrm{IC}_{50}$ 


\section{Introduction}

Tetraspanin proteins play important roles during the life cycle of numerous viruses [1-5]. It has been suggested that virus entry involves specific tetraspanins such as cluster of differentiation (CD) tetraspanins CD9, CD63, CD81 and CD151, making them putative antiviral targets.

The widely expressed family of tetraspanin proteins is composed of 33 members in humans [6]. Tetraspanins localize in the plasma membrane and the membranes of intracellular compartments. They are structurally conserved harboring four transmembrane domains, three intracellular domains as well as a small and a large extracellular loop [7-11]. The large extracellular loop (LEL) of tetraspanins is a flexible functional domain with a variable sequence but different tetraspanins share a conserved structure [12-14]. Due to its ability to facilitate specific interactions, the LEL supports anchoring of multiple proteins to one site of the membrane $[9,12]$. The short cytoplasmic C-terminal tail of tetraspanins serves as a connector to cytoplasmic interaction partners [15-19]. Despite their relative shortness of about a dozen amino acids, some tetraspanin C-termini contain functional units, such as the C-termini of tetraspanins CD63 and CD151 that contain a tyrosine-based sorting motif essential for their subcellular localization [16,20]. Different tetraspanin domains can simultaneously interact with other tetraspanins or proteins from other protein families and thereby locally concentrate molecules in a functional network, the tetraspanin-enriched microdomains (TEMs or TERMs) [21,22]. The ability to form TEMs and co-integrate interaction partners such as growth factor receptors, adhesion molecules, and proteases into these assemblies enables local concentration of factors required for virus entry [5].

Human papillomaviruses (HPV) are small, nonenveloped DNA viruses infecting the skin and mucosa. Depending on the HPV type, infection causes either the formation of benign warts or malignant tumors. The high-risk HPV types are responsible for severe human cancers, including almost all cases of cervical cancer and numerous anogenital, head, and neck tumors [23,24]. High-risk HPV type 16 (HPV16) is most studied as it displays the highest oncogenic potential [25,26]. This HPV type requires a distinct set of receptors and accessory proteins such as tetraspanins [27-29], laminin-binding integrins [28,30-32], and growth factor receptors (GFRs) [33], for its uptake into the cell (reviewed in [34-36]). Tetraspanin CD151 is able to interact with these HPV16 entry factors [9,37] and mediates virus uptake via a clathrin-, caveolin- and dynamin-independent endocytic pathway $[28,38,39]$. Moreover, mutational analyses uncovered CD151 domains that are critical for endocytic uptake of HPVs, like the integrin-interacting domain of the LEL or the cytoplasmic C-terminus [28,39]. Following endocytosis, virions are trafficked via endosomal structures. This post-endocytic trafficking requires tetraspanin CD63 [40]. Here again, the functionality of its C-terminus is required for HPV16 infection as it is essential for the interaction with the adaptor protein syntenin-1 [16,40]. CD63/syntenin-1 complex formation ensures HPV trafficking to multivesicular bodies. This step is vital for viral capsid disassembly, and mediates the delivery of the viral genome to the host cell nucleus [40]. Additionally, HPV infection induces clustering of CD81 on T-cell membranes leading to the formation of large cluster networks required for viral uptake [29]. Therefore, in addition to CD151 and CD63, other tetraspanins might be involved in HPV infection as it has been shown for other viruses like HCMV [3-5,41].

Human cytomegalovirus (HCMV), an enveloped DNA virus and member of the herpesviridae family, can cause life-threatening disease in immunocompromised individuals and is among the leading causes of infection-related birth defects [42,43]. At present, there is no vaccine that provides sufficient protection from HCMV infection, therefore the need to identify new antiviral drug targets remains. For successful entry into certain cell types, such as epithelial and endothelial cells, HCMV requires several cellular factors such as tetraspanin proteins CD9, CD63, CD81, and CD151 [4,41], integrins [44,45], growth factor receptors (epidermal GFR and platelet-derived GFR alpha) as well as neuropilin-2 which have been separately investigated [46-48].

In this study, the general requirements of the tetraspanins CD9, CD63, CD81, and CD151 in infections by the most oncogenic HPV type, HPV16, were tested as previously investigated for HCMV. Although future research is required to identify the precise role of tetraspanins CD9 and CD81, our study is the first to define them as novel players in HPV16 infection. Furthermore, we analyzed the 
involvement of specific tetraspanin domains, the LEL and the C-terminus, in HPV and HCMV infection by using recombinant peptides or proteins comprising these domains of CD9, CD63, CD81 and CD151 tetraspanins. We demonstrate that C-terminal peptides of CD63 and CD151 exhibit a moderate to potent inhibitory effect on HPV16 and HCMV infections. These findings suggest that the function of the C-terminus of CD151 and CD63 but not of CD9 is of particular importance for virus entry and infection. In conclusion, our results highlight the C-terminal tails of CD63 and CD151 as effective HPV16 and HCMV entry inhibitors. Moreover, we find peptides of functional tetraspanin domains as useful tools to investigate the role of tetraspanins and their domains in virus infections.

\section{Results}

\subsection{Cluster of Differentiation (CD) Tetraspanins CD9, CD63, CD81 and CD151 Are Required for Human Papillomavirus Type 16 (HPV16) Infection.}

Tetraspanin assemblies play an important role in virus entry [5]. It has been shown that CD9, CD81 and CD151 were downregulated during HCMV entry and that cellular depletion of CD9, CD63 and CD151 reduced HCMV infection [4,41]. Oncogenic HPV types utilize TEMs with tetraspanin CD151 as a key player during endocytosis [28,38]. Moreover, tetraspanin CD63 is crucial for post-endocytic virus trafficking, ensuring delivery of the viral DNA to the host cell nucleus [40]. In addition, we have shown earlier that neutralizing antibodies specific for CD63 and CD151 reduced infectivity in HEK293TT cell line [27-29]. The importance of tetraspanins CD9 and CD81 for HPV infection has not yet been revealed. To test whether additional tetraspanins are involved in HPV16 infection, we applied a pseudovirus (PsV) infection assay, depleting either CD9 or CD81. siRNAs targeting CD151 and CD63 served as a control for impaired infection. HeLa cells were incubated with specific tetraspanin siRNAs as indicated for $48 \mathrm{~h}$ before infection with HPV16 PsVs. All tested tetraspanin siRNAs induced a significant reduction in HPV16 infection rates (Figure 1). Cellular depletion of CD81 induced a weak infection rate inhibition of 25 to $30 \%$. Knockdown of CD63 displayed a reduction of infection by more than $50 \%$ and CD9 knockdown resulted in a strong inhibition of about $90 \%$, which was comparable to results obtained by CD151 siRNAs. Since the knockdown efficiency of tetraspanin CD63 is stronger than the assessed infectivity after its depletion, it is likely that another tetraspanin might overtake the role of CD63. Together, these results emphasize the role of different tetraspanins in HPV infection and uncover the importance of CD9 for infection of HeLa cells.
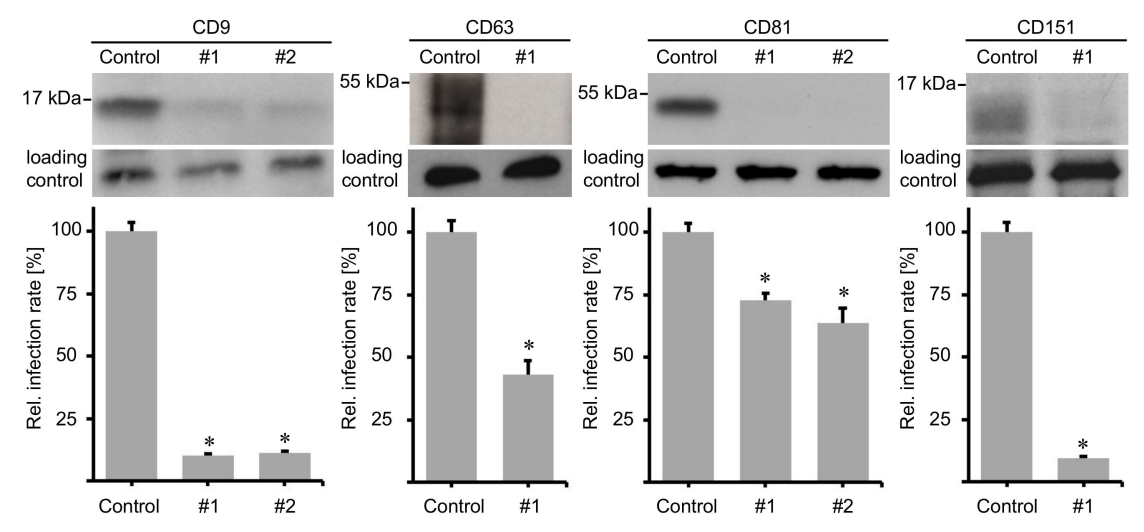

Figure 1. Tetraspanins CD9, CD63, CD81, and CD151 are required for HPV16 infection. HeLa cells were treated with control, tetraspanin CD9, CD63, CD81 or CD151 specific siRNAs (\#1 or \#2) for $48 \mathrm{~h}$, then infected with HPV16 PsVs for $24 \mathrm{~h}$. Upper panels show siRNA knockdown efficiency ( $\beta$-actin served as loading control). Graphs presented on the lower panels show relative infection rates assessed by measuring luciferase activity since HPV16 PsVs harbor a luciferase expression plasmid. Data sets are shown as mean \pm standard error of the mean (SEM) and were normalized to the mean of control siRNA treated cells (set to $100 \%$ ). Asterisks indicate significant differences to the control $(p<0.05)$. 


\subsection{Peptides Comprising the Large Extracellular Loop of Tetraspanins Interfere with HPV16 Infection.}

The large extracellular loop of tetraspanin proteins is a variable functional region. It mediates tetraspanin interactions with other tetraspanin molecules or interacting partner proteins [12-14,29,49], thereby contributing to the formation of functional tetraspanin-enriched microdomains. Recombinant proteins comprising LELs of tetraspanins involved in HPV and HCMV entry might inhibit infection by competitively binding PsVs or tetraspanin interaction partners. To this end, LEL-GST (glutathione $S$-transferase) fusion proteins of tetraspanins CD9, CD63, CD81 or CD151 were produced and purified as previously demonstrated [50]. HeLa and $\mathrm{HaCaT}$ cells were incubated with these recombinant LELs for $1 \mathrm{~h}$ and subsequently infected with HPV16 PsVs. The LELs of CD63, CD81 and CD151 induced a minor, but significant reduction of HPV infection rates in HeLa and HaCaT cells at $24 \mathrm{~h}$ post infection (h.p.i.) (Figure 2A). To test whether the LELs affect HCMV infection, EA.hy926 cells were incubated with the recombinant proteins and subsequently infected with HCMV strain TB40/E. At 24 h.p.i., the cells were fixed and the fraction of infected cells expressing viral immediate early antigen (IE-Ag) was determined via immunofluorescence. None of the tested tetraspanin peptides affected HCMV infection (Figure 2B). These results suggest that proteins comprising the LELs of CD9, CD63, CD81 and CD151 have a weak inhibitory effect on HPV infection and no effect on HCMV infection.
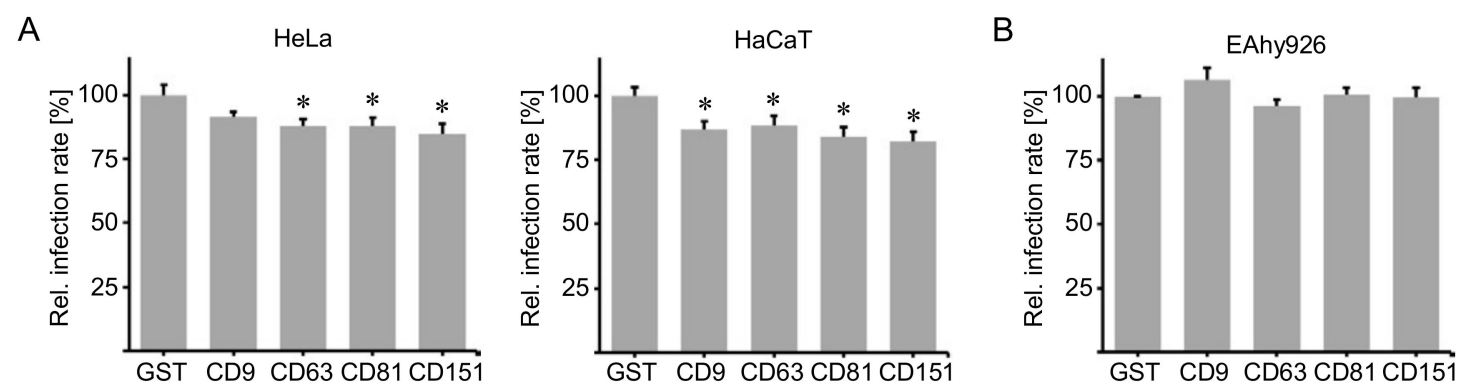

Figure 2. Peptides comprising the large extracellular loop of tetraspanins interfere with HPV16 infection. (A) HeLa and HaCaT cells were incubated with $500 \mathrm{nM}$ glutathione $S$-transferase (GST) negative control protein or GST fusion proteins comprising the large extracellular loop of tetraspanin CD9, CD63, CD81 or CD151 for $3 \mathrm{~h}$. Cells were infected with HPV16 PsVs and relative infection rate was assessed by measuring luciferase activity $24 \mathrm{~h}$ post infection (h.p.i.). (B) EA.hy926 cells were incubated with $500 \mathrm{nM}$ GST negative control protein or GST fusion proteins of the large extracellular loop of tetraspanin CD9, CD63, CD81, or CD151 for $2 \mathrm{~h}$. Cells were infected with HCMV strain TB40/E and analyzed via immunofluorescence. The fraction of infected cells was calculated by dividing the number of immediate early antigen (IE-Ag) positive cells by the number of DAPI positive nuclei 24 h.p.i. The data is shown as mean \pm SEM and was normalized to the mean of control peptide (GST) treated cells (set to 100\%). Asterisks indicate significant differences compared to control $(p<0.05)$.

\subsection{Blocking Peptides of the Cytoplasmic C-Terminal Tail of Tetraspanins Inhibit HPV16 Infection.}

The cytoplasmic C-terminal domain of tetraspanins is a functional region required for interaction with cytoplasmic partner proteins [15-19]. The C-terminus of CD63 facilitates complex formation between CD63 and its direct interaction partner syntenin-1 [16], which is required for post-endocytic trafficking of HPV [40]. Moreover, HPV infection involves the C-terminus of CD151 [28], which affects integrin functions and links CD151 to intracellular pathways [51-54]. Therefore, we used cytopermeable peptides comprising the C-terminal region sequence as inhibitors of tetraspanin functions. These peptides have been shown to block some tetraspanin-dependent functions having the same functional effect than that of siRNA silencing [18]. In that sense, HeLa and HaCaT cells were incubated with a control peptide comprising the scrambled combination of the ten amino acids of CD81 C-terminus (Cont.), as well as peptides containing the C-terminal sequence of tetraspanins CD9, CD63, CD81 and CD151, or a pool of these peptides and subsequently exposed to HPV16 PsVs. The C-terminal peptides of tetraspanins CD63 and CD151 significantly reduced HPV infection rates in 
HeLa cells 24 h.p.i. In HaCaT cells, the C-terminal peptides of tetraspanin CD63, CD81 and CD151 as well as the pool of all tested peptides significantly decreased HPV infection rates 24 h.p.i. (Figure 3A).

Although the recombinant peptides used are able to enter the cell [18], we applied the protein delivery reagent PULSin to test whether the inhibitory effect of C-terminal peptides could be enhanced by an increased cytoplasmic delivery of the peptides. HeLa and HaCaT cells were treated with peptides pre-incubated with PULSin for $1 \mathrm{~h}$ before exposure to HPV16 PsVs. Indeed, the addition of the PULSin reagent increased the inhibitory effect of HPV infection rates. In HeLa cells, C-terminal CD63, CD81 and CD151 peptides as well as the peptide pool significantly reduced HPV infection rates, whereas in $\mathrm{HaCaT}$ cells all tested C-terminal peptides induced a significant reduction of the HPV infection rate (Figure 3B).

In summary, the C-terminal peptides of tetraspanins CD63 and CD151 showed the strongest effects on infection rates.

A

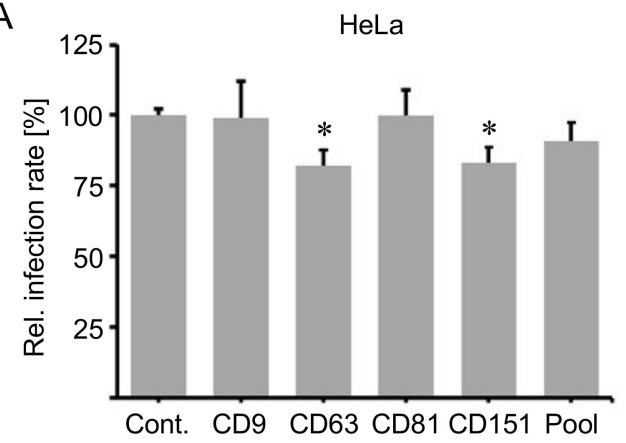

B

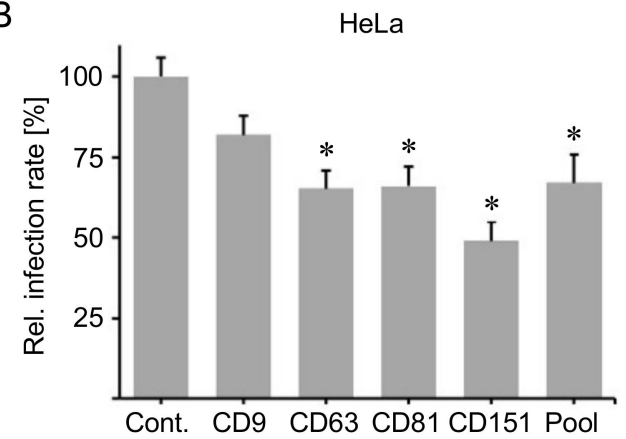

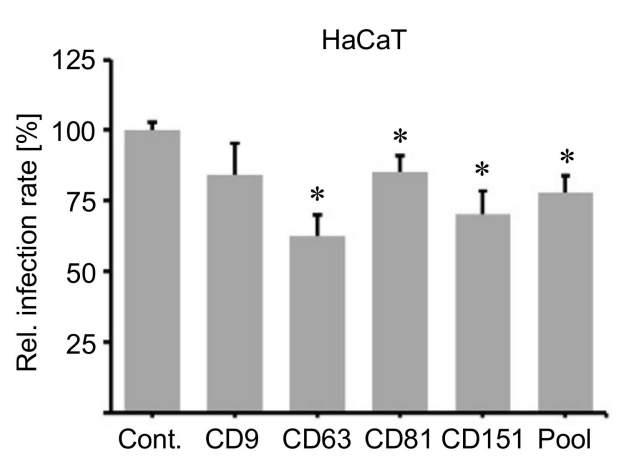

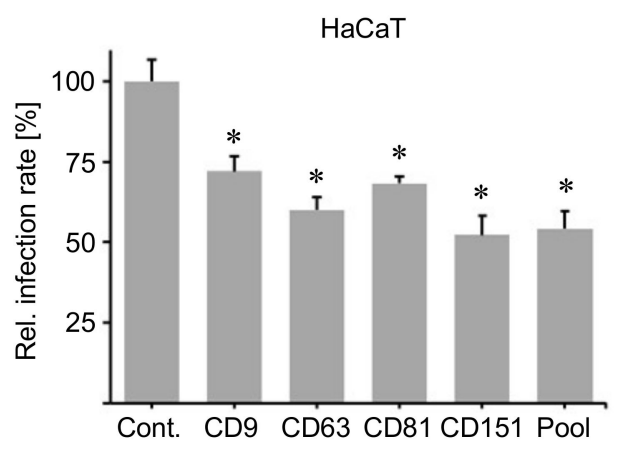

Figure 3. Blocking peptides of the cytoplasmic C-terminal tail of tetraspanins inhibit HPV16 infection. (A) HeLa and $\mathrm{HaCaT}$ cells were incubated with $2 \mu \mathrm{M}$ cytopermeable control peptide (scrambled amino acid sequence of CD81; Contr.) or peptides comprising the cytoplasmic C-terminal tail of tetraspanin CD9, CD63, CD81, CD151, or a pool of the CD9, CD63, CD81 and CD151 peptides (Pool) using $0.5 \mu \mathrm{M}$ of each peptide for $1 \mathrm{~h}$. Next, the cells were infected with HPV16 PsVs and relative infection rate was assessed by measuring luciferase activity 24 h.p.i. (B) HeLa and HaCaT cells were treated as in A but the PULSin transfection reagent was present for $1 \mathrm{~h}$ to increase cytoplasmic delivery of the peptides. Next, the cells were infected with HPV16 PsVs and relative infection rate was assessed by measuring luciferase activity 24 h.p.i. The data is shown as mean \pm standard error of the mean (SEM) and was normalized to the mean of control peptide treated cells (set to 100\%). Asterisks indicate significant differences compared to control $(p<0.05)$.

Next, the half-maximal inhibitory concentration $\left(\mathrm{IC}_{50}\right)$ of the most effective peptides, $\mathrm{CD} 63$ and CD151, was determined. To exclude the cellular toxicity or other side effects of PULSin, the IC $_{50}$ was performed without any enhancers of transfection. The $\mathrm{IC}_{50}$ categorizes inhibitors into three classes: potent $\left(\mathrm{IC}_{50}<1 \mu \mathrm{M}\right)$, moderate $\left(1 \mu \mathrm{M}<\mathrm{IC}_{50}<10 \mu \mathrm{M}\right)$, or weak $\left(\mathrm{IC}_{50}>10 \mu \mathrm{M}\right)$ inhibitors [55-57]. The dose-response curves and calculated $\mathrm{IC}_{50}$ of the C-terminal CD63 and CD151 peptides in HPV infection as well as the assessed 95\% confidence interval (95\% CI) are shown in Figure 4. 
A

HeLa

$\mathrm{HaCaT}$
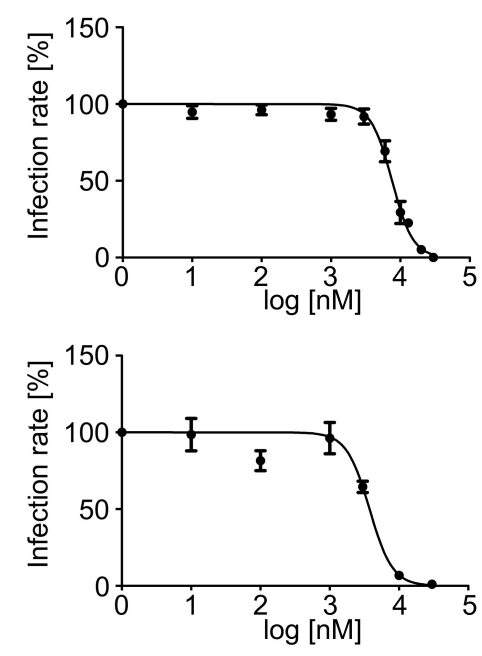

CD63 peptide
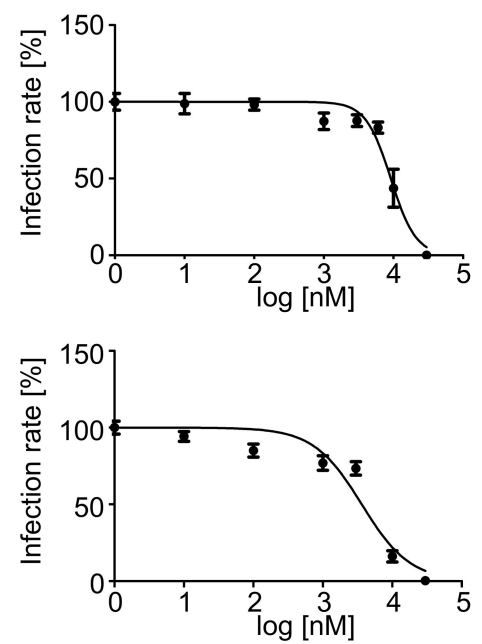

B

\begin{tabular}{l|c|c}
\multicolumn{1}{c}{$\mathbf{I C}_{50}[\boldsymbol{\mu M}]$} & $\mathbf{9 5 \%} \mathrm{Cl}[\boldsymbol{\mu M}]$ \\
\hline CD151 & 7.60 & $6.83-8.46$ \\
CD63 & 9.16 & $7.49-11.21$ \\
\hline CD151 & 3.76 & $2.95-4.79$ \\
CD63 & 3.64 & $2.76-4.79$ \\
\hline
\end{tabular}

Figure 4. Dose-response curves (A) and $\mathrm{IC}_{50}$ with $95 \% \mathrm{CI}$ values (B) of C-terminal peptides of CD63 and CD151 in HPV16 infection. Cells were incubated with C-terminal peptides at final concentrations ranging from 1 to $30,000 \mathrm{nM}$ for $1 \mathrm{~h}$. Afterwards, the cells were infected with HPV16 PsVs. Pseudovirus infection assays were performed $24 \mathrm{~h}$ after PsVs addition. The data is shown as mean $\pm \mathrm{SEM}$.

2.4. Blocking Peptides of the Cytoplasmic C-Terminal Tail of Tetraspanins Inhibit Human Cytomegalovirus (HCMV) Infection.

To examine the inhibitory effect of the blocking peptides against the C-terminal tails of tetraspanins in a second viral infection model, EA.hy926, HEC-LTT (human endothelial cell-large T antigen and telomerase) and HFF (human foreskin fibroblast) cells were incubated with blocking peptides of the C-terminal tail of tetraspanins CD9, CD63, CD81, and CD151 or the control peptide and then exposed to the HCMV strain TB40/E. Peptides comprising the C-terminal CD9 and CD81 peptide had only minor effects on HCMV infection. However CD81 peptide significantly increased HCMV infection in EAhy926 cells, which might be a cell line specific effect. The peptide comprising the cytoplasmic C-terminal tail of CD151 significantly reduced HCMV infection rates in EA.hy926 and HEC-LTT cells, while the peptide of the cytoplasmic C-terminal tail of CD63 significantly decreased HCMV infection rates in all cell lines tested (Figure 5). 

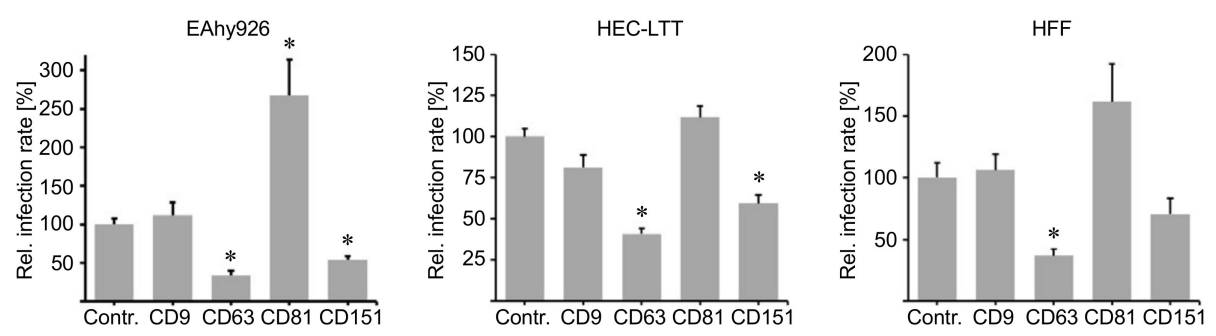

Figure 5. Blocking peptides of the cytoplasmic C-terminal tail of tetraspanins inhibit HCMV infection. EA.hy926, HEC-LTTs or HFF cells were incubated with $2 \mu \mathrm{M}$ scrambled control peptide (Contr.) or peptides with the C-terminal tail of CD9, CD63, CD151 for $2 \mathrm{~h}$ at $37{ }^{\circ} \mathrm{C}$. Afterwards, the cells were infected with the HCMV strain TB40/E and 24 h.p.i. fixed with $80 \%$ acetone. The fraction of infected cells, IE-Ag positive, was determined by immunofluorescence. The data is shown as mean \pm SEM and was normalized to the mean of control peptide treated cells (set to $100 \%$ ). Asterisks indicate significant differences compared to control $(p<0.05)$. Graphs represent data collected from two independent experiments.

As found in HPV infection inhibition assays, peptides harboring the sequence of the C-terminus of CD63 and CD151 displayed the strongest effect. Based on these findings, the dose-response curves and $\mathrm{IC}_{50}$ of CD63 and CD151 in HCMV infection were determined as shown in Figure 6.

A

EA.hy926

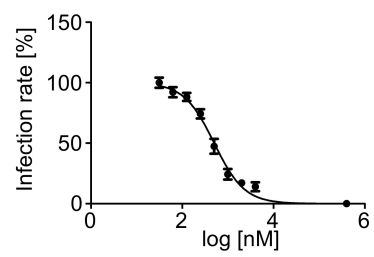

HEC-LTT
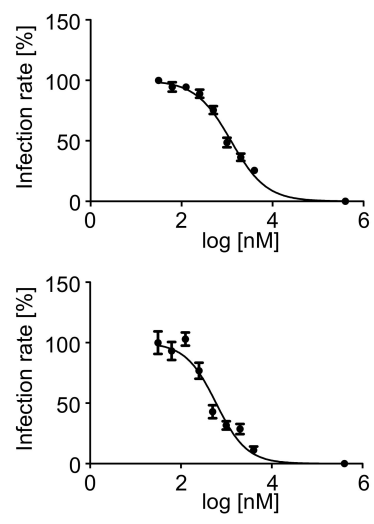

CD63 peptide
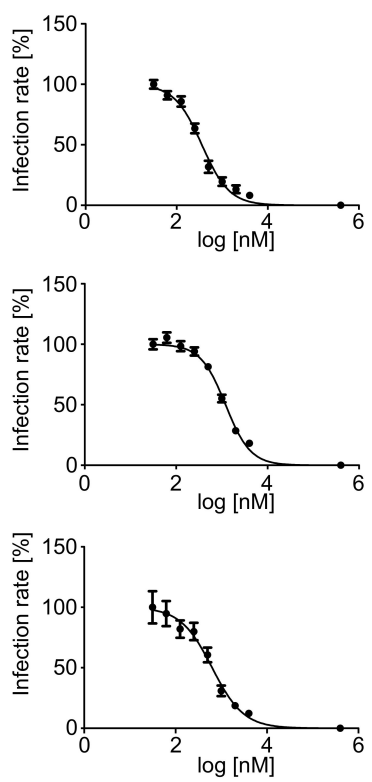

B

EA.hy926

\begin{tabular}{l|c|c}
\multicolumn{1}{c}{} & $\mathbf{I C}_{50}[\boldsymbol{\mu M}]$ & $\mathbf{9 5 \%} \mathrm{CI}[\boldsymbol{\mu M}]$ \\
\hline $\mathrm{CD} 151$ & 0.50 & $0.43-0.58$ \\
$\mathrm{CD63}$ & 0.36 & $0.31-0.40$ \\
\hline $\mathrm{CD} 151$ & 1.22 & $1.07-1.39$ \\
$\mathrm{CD63}$ & 1.20 & $1.08-1.34$ \\
\hline $\mathrm{CD} 151$ & 0.60 & $0.48-0.74$ \\
$\mathrm{CD63}$ & 0.63 & $0.48-0.82$ \\
\hline
\end{tabular}

Figure 6. Dose-response curves (A) and $\mathrm{IC}_{50}$ with 95\% CI values (B) of C-terminal peptides of CD63 and CD151 in HCMV infection. C-terminal peptides were used at final concentrations ranging from 30 to $4000 \mathrm{nM}$. The cells were incubated with peptide for $2 \mathrm{~h}$, infected with TB40/E virus and incubated for $2 \mathrm{~h}$ at $37^{\circ} \mathrm{C}$. The fraction of IE-Ag positive cells was analyzed by immunofluorescence staining. The data is shown as mean \pm SEM. 


\subsection{C-Terminal Peptides of CD63 and CD151 Inhibit HPV16 Entry.}

During HPV entry, the disassembly of the viral capsid is required for the delivery of the viral genome into the nucleus. CD63- and CD151-depleted cells show significantly decreased capsid disassembly [28,40]. To test whether C-terminal CD63 and CD151 peptides affect HPV capsid disassembly, we used the disassembly specific L1 antibody (L1-7) recognizing an epitope of the HPV major capsid protein L1 that is only accessible post internalization and capsid disassembly [27,58], as well as the polyclonal L1 antibody K75 detecting all bound and internalized viral particles $[27,59,60]$ as a control for the total amount of viral particles. HaCaT cells were transfected with peptides, incubated with HPV16 PsVs for $7 \mathrm{~h}$ and analyzed via immunofluorescence. C-terminal CD63 peptide-treated cells showed the fluorescently labeled peptides throughout the cytoplasm, matching the cellular location of CD63 cytoplasmic interaction partner syntenin-1 $[16,40]$. In contrast, fluorescently labeled C-terminal CD151 peptides were observed in proximity to the plasma membrane, were L1 staining by polyclonal K75 antibody was mainly detected, suggesting that virus endocytosis was blocked by the CD151 peptides. Control peptide-transfected cells readily displayed L1-7 staining, as well as K75 staining. In C-terminal CD63- and CD151-peptide transfected cells L1-7 staining was significantly decreased compared to the control, whereas K75 staining was readily detectable (Figure 7). These results are in line with the indicated competitive inhibitor potency of C-terminal CD63 and CD151 peptides (Figure 3). Our results suggest that the inhibitory effect of C-terminal CD63 and CD151 peptides occurs prior to HPV capsid disassembly conforming to the role of CD63 and CD151 during HPV entry $[28,40]$.

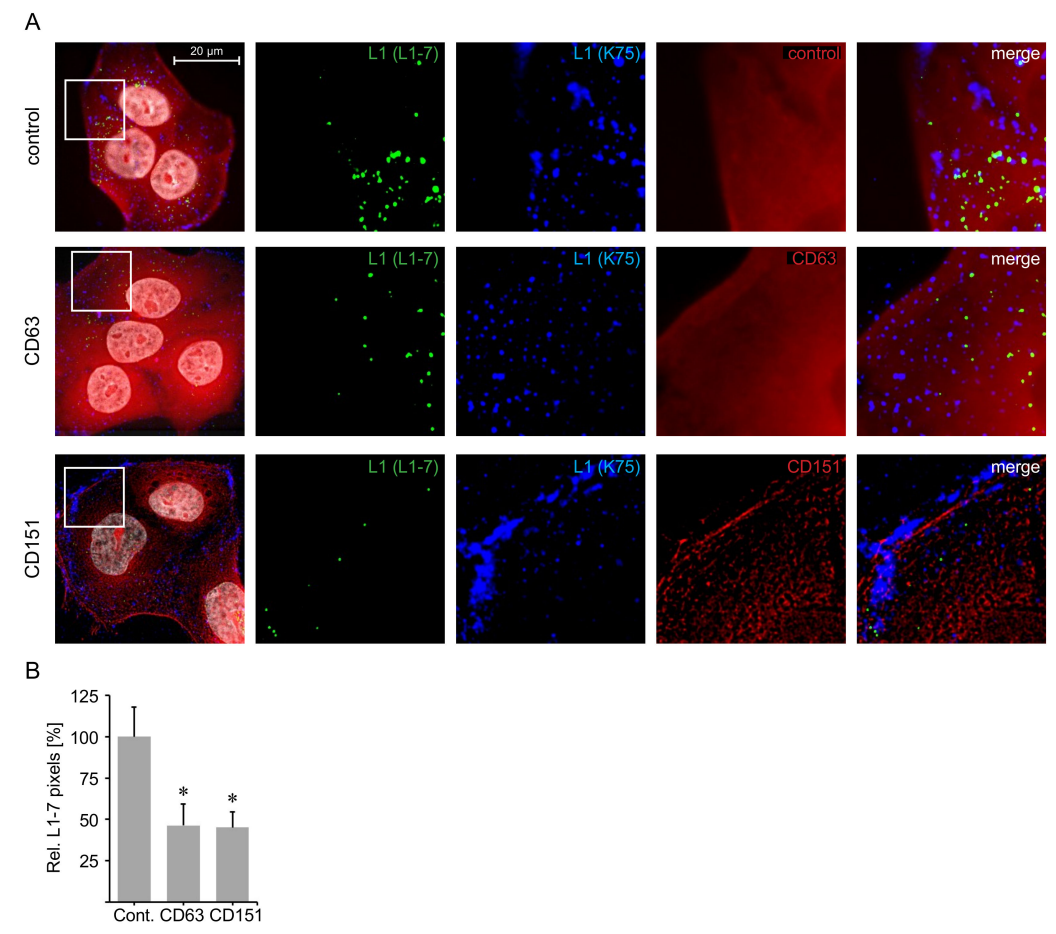

Figure 7. C-terminal peptides of CD63 and CD151 inhibit HPV16 entry. HaCaT cells were transfected with $2 \mu \mathrm{M}$ of control peptide or peptides comprising the cytoplasmic C-terminal tail of tetraspanin CD63 or CD151, mixed with PULSin transfection reagent $1 \mathrm{~h}$ prior addition to the cells. Afterwards, the cells were incubated with HPV16 PsVs for $7 \mathrm{~h}$ and stained by immunofluorescence. (A) Representative pictures of immunofluorescence with HPV16 L1 monoclonal antibody L1-7 (green), polyclonal antibody K75 (blue), specified peptide (red) and Hoechst for DNA staining (white). L1-7 recognizes the HPV16 L1-7 epitope accessible after HPV internalization and capsid disassembly. K75 recognizes all bound and internalized HPV particles. (B) Quantification of relative L1-7 per DNA pixels. Data is shown as mean \pm SEM and was normalized to the mean of control peptide (Cont.) transfected cells (set to 100\%). Analysis was performed on 20 images per group using ImageJ software. Asterisks indicate significant differences compared to control $(p<0.05)$. 


\section{Discussion}

A multitude of viruses require tetraspanin proteins for infection making tetraspanins compelling antiviral targets. In this study we compared the importance of tetraspanins CD9, CD63, CD81 and CD151 in infections by human papilloma- and cytomegalovirus and investigated whether peptides of functional tetraspanin domains could be used as inhibitors of HPV and HCMV infection.

Until now, the role of tetraspanins CD9 and CD81 in HPV infection remains poorly defined. Our experiments with siRNA-mediated knockdown of CD9 and CD81 in HeLa cells highlighted the importance of both tetraspanins in HPV16-mediated infection. CD9-targeting siRNAs reduced the HPV infection rate to an extent similar to the siRNA directed against CD151, whose crucial role in HPV infection was stated earlier $[27,28,38]$. A significant reduction of infection by nearly $90 \%$ after CD9 depletion makes this tetraspanin an interesting target of investigation for future HPV research. In comparison, CD81 depletion reduced HPV16 infection by approximately $30 \%$. This was comparable to a previous study showing that the inhibitory effect of antibodies against CD81 was weaker than that of antibodies against CD63 and CD151 in HPV16 infection [27]. These results indicate that different tetraspanins have individual potencies in benefitting HPV infection. CD81 seems to play a minor role in HPV infection, whereas CD9 is likely to be a major player.

LELs are functional tetraspanin domains that have previously been shown to be involved in viral infection $[14,29,61,62]$. However, our data shows that soluble proteins comprising the LELs of CD9, CD63, CD81 and CD151 inhibit HPV infection to a significant but minor extent and pose no effect on HCMV infection. These findings are in strong contrast to the results reported for infection with human immunodeficiency virus (HIV), in which recombinant CD9, CD63, CD81 and CD151 LELs were identified as potent inhibitors [61]. Moreover, it was shown that recombinant CD81 LEL proteins are able to sufficiently bind Hepatitis $C$ virus by interacting with its major virus envelope protein E2 [63], implying that LEL proteins are capable of competitively interacting with virions. Our results suggest that the LEL proteins do not capture HPV or HCMV virions nor interfere with other tetraspanin interactions involved in HPV and HCMV infection. Therefore, the antiviral potency of LEL proteins might be virus specific and requires further investigation.

More importantly, we show that cytopermeable peptides comprising the C-termini of CD63 and CD151 had a moderate to potent inhibitory effect on HPV16 and HCMV infections in different cell lines. Simultaneous addition of all tested tetraspanin peptides was unable to increase the effect of the individual peptides. Interestingly, CD9-targeting siRNAs caused a significant reduction of HPV (Figure 1) and HCMV [4] infections, whereas the C-terminal peptide had no or only a minor inhibitory effect. This discrepancy of the consequences of cellular depletion versus treatment of cells with CD9 C-terminal peptides might imply that CD9 affects HPV and HCMV infection via a function that does not involve C-terminal dependent cytoplasmic interactions. Therefore it is likely that CD9 benefits HPV and HCMV infection by organization of virus entry platforms (TEMs) [5] or the modulation of the activity or accessibility of interaction partners like proteases as it was proposed for entry of MERS viruses [64].

Overall, concentration curves of blocking peptides against the cytoplasmic C-terminal tail of tetraspanins CD63 and CD151 produced effective reduction in both viral infection systems and in all tested cell models, indicating that these peptides might be useful for development of HPV and HCMV inhibitors. This is in line with previous studies demonstrating that CD63 and CD151 are involved in HPV and HCMV infection and that the C-terminal domains of these tetraspanins are indispensable for their role in virus infection $[4,27,28,38,40]$. Moreover, the comparable effects of siRNA and C-termini treatment suggests that these two viruses take advantage of similar cellular pathways during infectious entry.

Mechanistically, we show that the CD63 and CD151 C-terminal peptides decreased the disassembly of HPV16 capsids which consequently inhibited infection. We observed differences in the cellular localization of the CD63 and CD151 peptides which might indicate the localization of the tetraspanin interaction partners. Direct interaction of CD63 C-terminus has been previously 
reported for the cytoplasmic adaptor proteins syntenin-1 [16] and AP subunits [17]. However, little is known about direct interactions facilitated by the CD151 C-terminus [12]. Moreover, distribution of the HPV16 capsid protein L1 indicates that C-terminal CD151 peptide is able to block virus endocytosis as the capsid protein was mainly detected in the cell periphery. On the other hand, cells treated with the CD63 peptide displayed evenly distributed capsid staining throughout the cytoplasm accompanied by reduced capsid disassembly suggesting inhibited intracellular trafficking and endosomal maturation. These findings are in line with the effect described for cellular depletion of these tetraspanins [28].

Our data suggests that the tetraspanin C-terminal peptides can specifically block the function of the corresponding tetraspanin domains, making them suitable reagents for investigating the role of tetraspanins in their diverse cellular functions. Furthermore, with assessed $\mathrm{IC}_{50}$ values lower than $1 \mu \mathrm{M}$ for HCMV and lower than $10 \mu \mathrm{M}$ for HPV, the C-terminal peptides of CD63 and CD151 can be classified as potent and moderate antiviral agents for HCMV and HPV infection, respectively, making them an interesting tool for entry prevention of other viruses.

\section{Materials and Methods}

\subsection{Cell Lines and Pseudoviruses}

The human cervical carcinoma cell line HeLa was purchased from the German Resource Centre for Biological Material (DSMZ, Braunschweig, Germany). The human nonvirally immortalized keratinocyte cell line HaCaT was purchased from Cell Lines Services (CLS, Eppelheim, Germany). Cells were grown in Dulbecco's modified Eagle's medium (DMEM + GlutaMAX, Thermo Fisher Scientific, Waltham, MA, USA) supplemented with 10\% fetal calf serum (FCS), 1\% minimum essential medium nonessential amino acids (MEM nonessential amino acids, Thermo Fisher Scientific, Waltham, MA, USA) and the antibiotic ciprofloxacin.

Human foreskin fibroblast (HFF), primary cells isolated from human tissue, were grown in MEM + GlutaMAX (Life Technologies, Darmstadt, Germany) supplemented with 5\% FCS, basic fibroblast growth factor $(0.5 \mathrm{ng} / \mathrm{mL})$ and the antibiotic gentamicin $(100 \mu \mathrm{g} / \mathrm{mL})$.

EA.hy926 cells (ATCC CRL-2922), a hybrid cell line previously generated by fusion of human umbilical vein endothelial cells (HUVEC) and A-549 cells was purchased from LGC Standards (Wesel, Germany). Cells were grown in DMEM + GlutaMAX (Life Technologies), 10\% FCS and antibiotic gentamicin [65].

Human endothelial cell-large T antigen and telomerase (HEC-LTT), a conditionally immortalized cell line generated from human umbilical vein endothelial cells (HUVEC) by introducing doxycycline-inducible gene expression cassettes for the simian virus 40 (SV40) large T antigen and the human telomerase catalytic subunit was kindly provided by Dagmar Wirth (Helmholtz Centre for Infection Research, Braunschweig). Cells were grown in EGM-BulletKit (CC-3124) (Lonza Sales Ltd., Basel, Switzerland): EBM (endothelial basal medium), bovine brain extract with heparin, human endothelial growth factor, hydrocortisone, ascorbic acid, GA-1000 (gentamicin, amphotericin B) and 2\% FCS. For passaging the culture medium was supplemented with doxycycline $(2 \mu \mathrm{g} / \mathrm{mL})$ immediately before addition to the cells [65].

HPV16 pseudoviruses were prepared as described earlier [66]. HCMV strain TB40/E was originally isolated from a throat wash specimen obtained from a bone marrow transplant patient and subsequently propagated in HUVECs [67].

\section{2. $C D 9, C D 63, C D 81$ and $C D 151$ siRNA Knockdown}

CD9\#1 (Hs_CD9_1), CD9\#2 (Hs_CD9_7), CD81\#1 (Hs_CD81_11), and CD81\#2 (Hs_CD81_6) were purchased from Qiagen (Hilden, Germany). CD63\#1 and CD151\#1 were purchased from Sigma-Aldrich (St. Louis, MO, USA), and have been described previously [28,40]. Sequences are available upon request. Non-silencing control siRNA (AllStars Neg. Control siRNA, Qiagen) was used as control. HeLa cells were 
transfected with $30 \mathrm{nM}$ siRNA using Lipofectamine RNAiMAX (Invitrogen, Carlsbad, CA, USA) for $48 \mathrm{~h}$ according to manufacturer's instructions. Knockdown efficiency was quantified by Western blotting.

\subsection{Antibodies}

Mouse monoclonal CD9 and CD81 antibodies were purchased from Acris (Rockville, MD, USA) and Santa Cruz (Dallas, TX, USA), respectively. CD63 and CD151 antibodies were described earlier [28,40]. The HPV L1-specific antibodies mouse monoclonal antibody L1-7 and rabbit polyclonal antibody K75 were described previously [27,58,68]. Anti-IE-Ag (clone E13), mouse monoclonal antibody targeted against viral immediate early antigens 1 and 2 was purchased from Argene (Verniolle, France). Secondary, Cy3-conjugated goat polyclonal anti-mouse-Ig F(ab')2 antibody was from Jackson ImmunoResearch (Baltimore, MD, USA).

\subsection{LEL Proteins and C-Terminal Peptides}

Recombinant fusion proteins mimicking the large extracellular loop of tetraspanins CD9, CD63, CD81 and CD151 as well as the glutathione S-transferase (GST) fusion partner were produced in E. coli and purified as previously described [50]. Peptides of the cytoplasmic C-terminal tail of tetraspanins CD9, CD63, and CD151 are tetramethylrhodamine (TAMRA) N-terminal-labeled peptides with the sequences RRRRRRRCCAIRRNREMV (CD9), RRRRRRRCCLVKSIRSGYEVM (CD63), RRRRRRRCLYRSLKLEHY (CD151) and were purchased from LifeTein (South Plainfield, NJ, USA) or DgPeptides (Hangzhou, Zhejiang, China). Peptides of the cytoplasmic C-terminal tail of CD81 as well as a CD81 scrambled negative control peptide have been described earlier [18,69].

\subsection{HPV Inhibition Assay}

HeLa and HaCaT cells were grown in 24- or 48-well plates and incubated with tetraspanin specific siRNAs, LELs or C-terminal peptides. Cells were infected with 100 luciferase vector positive HPV16 pseudoviruses per cell for $24 \mathrm{~h}$. Luciferase expression control and HPV pseudovirus infection assays were performed as described previously [28,70]. Luciferase counts were normalized to lactate dehydrogenase (LDH) to take the cell viability into account.

To determine the effect of recombinant LEL proteins, HeLa and HaCaT cells were incubated with specified LELs in medium without supplements for $3 \mathrm{~h}$ before exposure to HPV16 PsVs. To determine the impact of C-terminal tetraspanin peptides two approaches were used:

(1) The cells were incubated with C-terminal tetraspanin peptide in medium without supplements for $1 \mathrm{~h}$ and subsequently infected with PsVs.

(2) The cells were transfected with a mixture of C-terminal tetraspanin peptide and a PULSin (Polyplus-transfection, Illkirch, France) preincubated for $1 \mathrm{~h}$ in medium without supplements before PsVs addition and were further cultured in medium with FCS. PULSin was used according to manufacturer's instructions.

\subsection{HCMV Inhibition Assay}

To determine the effect of proteins comprising LELs or C-terminal tails, the cells were incubated with specified reagents for $2 \mathrm{~h}$ before infection with HCMV strain TB40/E. The fraction of infected cells (IE-Ag positive cells) was detected with immunofluorescence staining applying primary antibody against immediate early antigen (IE-Ag) and Cy3-conjugated secondary antibody as described before [4]. Nuclei were counterstained with DAPI. A Zeiss Axio Observer D1 microscope (Zeiss, Jena, Germany) was used for visualization of fluorescence. Strain TB40/E was used at a multiplicity of infection (MOI) of 0.5 to 1 . 


\section{7. $I C_{50}$ Determination}

To determine the $\mathrm{IC}_{50}$ (concentration necessary to achieve the half-maximal inhibition) for HPV, $\mathrm{HeLa}$ and $\mathrm{HaCaT}$ cells were incubated with C-terminal peptides at final concentrations ranging from 1 to $30,000 \mathrm{nM}$ for $1 \mathrm{~h}$ in medium without supplements. Afterwards, the cells were infected with about 100 luciferase vector positive HPV16 pseudoviruses per cell. Pseudovirus infection assays were performed $24 \mathrm{~h}$ after PsVs addition as described above. Luciferase counts were normalized to lactate dehydrogenase (LDH) to take the cell viability into account. Analysis was performed using GraphPad Prism 5 Software, Inc. (San Diego, CA, USA) (www.graphpad.com). The data were normalized to the mean of the smallest tested concentration that was set to $100 \%$.

To determine the $\mathrm{IC}_{50}$ for $\mathrm{HCMV}$, C-terminal peptides were used at final concentrations ranging from 30 to $4000 \mathrm{nM}$. The cells were incubated with peptide for $2 \mathrm{~h}$. Then, the cells were infected with TB40/E virus and incubated for $2 \mathrm{~h}$ at $37^{\circ} \mathrm{C}$. Afterwards, the medium containing the virus was exchanged by fresh medium supplemented with FCS. The fraction of infected cells, (IE-Ag positive cells) was then analyzed by immunofluorescence staining applying primary antibody for immediate early antigen (IE-Ag) and Cy3-conjugated secondary antibody. Analysis was performed using GraphPad Prism 5 Software, Inc. The data were normalized to the mean of the smallest tested concentration that was set to $100 \%$.

\subsection{Immunofluorescence}

HeLa or HaCaT cells were grown on cover slips. After transfection and/or infection, cells were fixed and permeabilized in methanol. Afterwards, cells were incubated with primary antibody and species-specific Alexa-conjugated secondary antibodies (Invitrogen). Nuclear DNA staining was achieved by incubation with Hoechst 33,342 (Sigma-Aldrich). Cover slips were mounted on microscope slides using Dako Fluorescent Mounting Medium (Dako, Carpinteria, CA, USA). Images were acquired using Zeiss Axiovert $200 \mathrm{M}$ microscope fitted with the Plan-Apochromat 100×/1.4 Oil objective and Axiovision deconvolution software (Carl Zeiss, Jena, Germany).

For determination of disassembled HPV16 PsVs (L1-7 epitope detection assay) HaCaT cells were grown on cover slips, transfected with C-terminal tetraspanin peptide for $1 \mathrm{~h}$ and infected with $100 \mathrm{HPV} 16$ pseudovirus particles per cell for $7 \mathrm{~h}$. Cells were fixed and permeabilized in methanol and stained with monoclonal antibody L1-7 as described in Spoden et al. 2008 [27]. Cover slips were mounted and images of 20 randomly selected cell islands per group were acquired as described above.

\subsection{Statistics}

If not stated otherwise, the experiments were repeated at least three times. Statistical analysis of all analyzable data points was assessed with two-tailed, unpaired $t$-tests using GraphPad Prism software and Microsoft Office Excel 2016. $p$-values smaller then $0.05(p<0.05)$ were considered as significant differences between groups.

Author Contributions: Conceptualization, L.A.F, S.M., M.Y.-M., D.L., and L.F.; formal analysis, L.A.F, S.M., and D.H.; investigation, L.A.F, S.M., A.F., J.S., F.B., and D.H.; resources, H.S. and P.M.; writing-original draft preparation, L.A.F, S.M., and L.F.; writing-review and editing, L.A.F, S.M., C.S., M.Y.-M., D.L., and L.F.; supervision, D.L. and L.F.; project administration, L.F.; funding acquisition, S.M., M.Y.-M., and L.F.

Funding: This research was funded by a fellowship of the German Academic Exchange Service (Deutscher Akademischer Austauschdienst, DAAD) to Snježana Mikuličić, by the Ministerio de Economía y Competitividad (BFU2014-55478-R and BIO2017-86500-R) to María Yáñez-Mó, and by the Deutsche Forschungsgemeinschaft (DFG; FL 696/2-1, FL 696/3-1) to Luise Florin.

Acknowledgments: We thank Linda Gräßel and Vera Magdalena Brasch for initial experiments as well as Sophie Möller for her critical reading of this manuscript.

Conflicts of Interest: The authors declare no conflicts of interest. 


\section{Abbreviations}

$\begin{array}{ll}\text { CD } & \text { cluster of differentiation } \\ \text { CI } & \text { confidence interval } \\ \text { DAPI } & 4^{\prime} \text {,6-Diamidin-2-phenylindol } \\ \text { FCS } & \text { fetal calf serum } \\ \text { GFR } & \text { growth factor receptor } \\ \text { GST } & \text { glutathion-S-transferase } \\ \text { HCMV } & \text { human cytomegalovirus } \\ \text { HEC-LTT } & \text { human endothelial cell-large T antigen and telomerase } \\ \text { HFF } & \text { human foreskin fibroblast } \\ \text { h.p.i. } & \text { hours post infection } \\ \text { HPV } & \text { human papillomavirus } \\ \text { IC } 50 & \text { half-maximal inhibitory concentration } \\ \text { IE-Ag } & \text { immediate early antigen } \\ \text { LDH } & \text { lactate dehydrogenase } \\ \text { LEL } & \text { large extracellular loop } \\ \text { MOI } & \text { multiplicity of infection } \\ \text { PsV } & \text { pseudovirus } \\ \text { SEM } & \text { standard error of the mean } \\ \text { TEM } & \text { tetraspanin-enriched microdomain }\end{array}$

\section{References}

1. Van Spriel, A.B.; Figdor, C.G. The role of tetraspanins in the pathogenesis of infectious diseases. Microbes Infect. 2010, 12, 106-112. [CrossRef] [PubMed]

2. Monk, P.N.; Partridge, L.J. Tetraspanins: Gateways for infection. Infect. Disord. Drug Targets 2012, 12, 4-17. [CrossRef] [PubMed]

3. Fast, L.A.; Lieber, D.; Lang, T.; Florin, L. Tetraspanins in infections by human cytomegalo- and papillomaviruses. Biochem. Soc. Trans. 2017, 45, 489-497. [CrossRef] [PubMed]

4. Hochdorfer, D.; Florin, L.; Sinzger, C.; Lieber, D. Tetraspanin CD151 promotes initial events in human cytomegalovirus infection. Am. Soc. Microbiol. 2016, JVI.00145-16. [CrossRef] [PubMed]

5. Florin, L.; Lang, T. Tetraspanin Assemblies in Virus Infection. Front. Immunol. Front. 2018, 9, 1140. [CrossRef] [PubMed]

6. Huang, S.; Yuan, S.; Dong, M.; Su, J.; Yu, C.; Shen, Y.; Xie, X.; Yu, Y.; Yu, X.; Chen, S.; et al. The phylogenetic analysis of tetraspanins projects the evolution of cell-cell interactions from unicellular to multicellular organisms. Genomics 2005, 86, 674-684. [CrossRef] [PubMed]

7. Charrin, S.; Jouannet, S.; Boucheix, C.; Rubinstein, E. Tetraspanins at a glance. J. Cell Sci. 2014, 127, 3641-3648. [CrossRef] [PubMed]

8. Hemler, M.E. Tetraspanin functions and associated microdomains. Nat. Rev. Mol. Cell Biol. 2005, 6, 801-811. [CrossRef] [PubMed]

9. Berditchevski, F.; Rubinstein, E. Tetraspanins; Springer: Dordrecht, The Netherlands, 2013.

10. Seigneuret, M. Complete predicted three-dimensional structure of the facilitator transmembrane protein and hepatitis C virus receptor CD81: Conserved and variable structural domains in the tetraspanin superfamily. Biophys. J. 2006, 90, 212-227. [CrossRef] [PubMed]

11. Zimmerman, B.; Kelly, B.; McMillan, B.J.; Seegar, T.C.; Dror, R.O.; Kruse, A.C.; Blacklow, S.C. Crystal Structure of a Full-Length Human Tetraspanin Reveals a Cholesterol-Binding Pocket. Cell 2016, 167, 1041-1051. [CrossRef] [PubMed]

12. Stipp, C.; Kolesnikova, T.; Hemler, M. Functional domains in tetraspanin proteins. Trends Biochem. Sci. 2003, 28, 106-112. [CrossRef]

13. DeSalle, R.; Mares, R.; Garcia-España, A. Evolution of cysteine patterns in the large extracellular loop of tetraspanins from animals, fungi, plants and single-celled eukaryotes. Mol. Phylogenet. Evol. 2010, 56, 486-491. [CrossRef] [PubMed] 
14. Rajesh, S.; Sridhar, P.; Tews, B.A.; Fénéant, L.; Cocquerel, L.; Ward, D.G.; Berditchevski, F.; Overduin, M. Structural basis of ligand interactions of the large extracellular domain of tetraspanin CD81. J. Virol. 2012, 86, 9606-9616. [CrossRef] [PubMed]

15. Sala-Valdés, M.; Ursa, Á.; Charrin, S.; Rubinstein, E.; Hemler, M.E.; Sánchez-Madrid, F.; Yáñez-Mó, M. EWI-2 and EWI-F link the tetraspanin web to the actin cytoskeleton through their direct association with ezrin-radixin-moesin proteins. J. Biol. Chem. 2006, 281, 19665-19675. [CrossRef] [PubMed]

16. Latysheva, N.; Muratov, G.; Rajesh, S.; Padgett, M.; Hotchin, N.A.; Overduin, M.; Berditchevski, F. Syntenin-1 is a new component of tetraspanin-enriched microdomains: Mechanisms and consequences of the interaction of syntenin-1 with CD63. Mol. Cell Biol. 2006, 26, 7707-7718. [CrossRef] [PubMed]

17. Rous, B.A.; Reaves, B.J.; Ihrke, G.; Briggs, J.A.; Gray, S.R.; Stephens, D.J.; Banting, G.; Luzio, J.P. Role of adaptor complex AP-3 in targeting wild-type and mutated CD63 to lysosomes. Mol. Biol. Cell 2002, 13, 1071-1082. [CrossRef] [PubMed]

18. Tejera, E.; Rocha-Perugini, V.; López-Martín, S.; Pérez-Hernández, D.; Bachir, A.I.; Horwitz, A.R.; Vázquez, J.; Sánchez-Madrid, F.; Yáñez-Mo, M. CD81 regulates cell migration through its association with Rac GTPase. Mol. Biol. Cell 2013, 24, 261-273. [CrossRef] [PubMed]

19. Perez-Hernandez, D.; Gutiérrez-Vázquez, C.; Jorge, I.; López-Martín, S.; Ursa, A.; Sánchez-Madrid, F.; Vázquez, J.; Yáñez-Mó, M. The intracellular interactome of tetraspanin-enriched microdomains reveals their function as sorting machineries toward exosomes. J. Biol. Chem. 2013, 288, 11649-11661. [CrossRef] [PubMed]

20. Berditchevski, F.; Odintsova, E. Tetraspanins as regulators of protein trafficking. Traffic 2007, 8, 89-96. [CrossRef] [PubMed]

21. Boucheix, C.; Rubinstein, E. Tetraspanins. Cell. Mol. Life Sci. 2001, 58, 1189-1205. [CrossRef] [PubMed]

22. Charrin, S.; Le Naour, F.; Silvie, O.; Milhiet, P.-E.; Boucheix, C.; Rubinstein, E. Lateral organization of membrane proteins: Tetraspanins spin their web. Biochem. J. 2009, 420, 133-154. [CrossRef] [PubMed]

23. Doorbar, J.; Quint, W.; Banks, L.; Bravo, I.G.; Stoler, M.; Broker, T.R.; Stanley, M.A. The biology and life-cycle of human papillomaviruses. Vaccine 2012, 30, F55-F70. [CrossRef] [PubMed]

24. Hausen zur, H. Papillomaviruses in the causation of human cancers-a brief historical account. Virology 2009, 384, 260-265. [CrossRef] [PubMed]

25. De Villiers, E.-M. Cross-roads in the classification of papillomaviruses. Virology 2013, 445, 2-10. [CrossRef] [PubMed]

26. Doorbar, J.; Egawa, N.; Griffin, H.; Kranjec, C.; Murakami, I. Human papillomavirus molecular biology and disease association. Rev. Med. Virol. 2015, 25, 2-23. [CrossRef] [PubMed]

27. Spoden, G.; Freitag, K.; Husmann, M.; Boller, K.; Sapp, M.; Lambert, C.; Florin, L. Clathrin- and caveolin-independent entry of human papillomavirus type 16-involvement of tetraspanin-enriched microdomains (TEMs). PLoS ONE 2008, 3, e3313. [CrossRef] [PubMed]

28. Scheffer, K.D.; Gawlitza, A.; Spoden, G.A.; Zhang, X.A.; Lambert, C.; Berditchevski, F.; Florin, L. Tetraspanin CD151 Mediates Papillomavirus Type 16 Endocytosis. J. Virol. 2013, 87, 3435-3446. [CrossRef] [PubMed]

29. Homsi, Y.; Schloetel, J.G.; Scheffer, K.D.; Schmidt, T.H.; Destainville, N.; Florin, L.; Lang, T. The extracellular $\delta$-domain is essential for the formation of CD81 tetraspanin webs. Biophys. J. 2014, 107, 100-113. [CrossRef] [PubMed]

30. Evander, M.; Frazer, I.H.; Payne, E.; Qi, Y.M.; Hengst, K.; McMillan, N.A. Identification of the alpha6 integrin as a candidate receptor for papillomaviruses. J. Virol. 1997, 71, 2449-2456. [PubMed]

31. McMillan, N.; Payne, E.; Frazer, I.; Evander, M. Expression of the [alpha] 6 Integrin Confers Papillomavirus Binding upon Receptor-Negative, B.-Cells. Virology 1999, 261, 271-279. [CrossRef] [PubMed]

32. Yoon, C.; Kim, K.; Park, S.; Cheong, S. [alpha] 6 Integrin Is the Main Receptor of Human Papillomavirus Type 16 VLP. Biochem. Biophys. Res. Commun. 2001, 283, 668-673. [CrossRef] [PubMed]

33. Surviladze, Z.; Dziduszko, A.; Ozbun, M.A. Essential Roles for Soluble Virion-Associated Heparan Sulfonated Proteoglycans and Growth Factors in Human Papillomavirus Infections. PLoS Pathog. 2012, 8, e1002519. [CrossRef] [PubMed]

34. Florin, L.; Sapp, M.; Spoden, G.A. Host-cell factors involved in papillomavirus entry. Med. Microbiol. Immunol. 2012, 201, 437-448. [CrossRef] [PubMed] 
35. Raff, A.B.; Woodham, A.W.; Raff, L.M.; Skeate, J.G.; Yan, L.; Da Silva, D.M.; Schelhaas, M.; Kast, W.M. The evolving field of human papillomavirus receptor research: A review of binding and entry. J. Virol. 2013, 87, 6062-6072. [CrossRef] [PubMed]

36. DiGiuseppe, S.; Bienkowska-Haba, M.; Guion, L.G.; Sapp, M. Cruising the cellular highways: How human papillomavirus travels from the surface to the nucleus. Virus Res. 2017, 231, 1-9. [CrossRef] [PubMed]

37. Bailey, R.L.; Herbert, J.M.; Khan, K.; Heath, V.L.; Bicknell, R.; Tomlinson, M.G. The emerging role of tetraspanin microdomains on endothelial cells. Biochem. Soc. Trans. 2011, 39, 1667-1673. [CrossRef] [PubMed]

38. Sutcliffe, S.; Viscidi, R.P.; Till, C.; Goodman, P.J.; Hoque, A.M.; Hsing, A.W.; Thompson, I.M.; Zenilman, J.M.; de Marzo, A.M.; Platz, E.A. Human papillomavirus types 16, 18, and 31 share similar endocytic requirements for entry. Am. Soc. Microbiol. 2013, 87, 7765-7773. [CrossRef]

39. Scheffer, K.D.; Berditchevski, F.; Florin, L. The tetraspanin CD151 in papillomavirus infection. Viruses 2014, 6, 893-908. [CrossRef] [PubMed]

40. Gräßel, L.; Fast, L.A.; Scheffer, K.D.; Boukhallouk, F.; Spoden, G.A.; Tenzer, S.; Boller, K.; Bago, R.; Rajesh, S.; Overduin, M.; et al. The CD63-Syntenin-1 Complex Controls Post-Endocytic Trafficking of Oncogenic Human Papillomaviruses. Sci. Rep. 2016, 6, 32337. [CrossRef] [PubMed]

41. Viswanathan, K.; Verweij, M.C.; John, N.; Malouli, D.; Früh, K. Quantitative membrane proteomics reveals a role for tetraspanin enriched microdomains during entry of human cytomegalovirus. PLoS ONE 2017, 12, e0187899. [CrossRef] [PubMed]

42. Leung, A.K.C.; Sauve, R.S.; Davies, H.D. Congenital cytomegalovirus infection. J. Natl. Med. Assoc. 2003, 95, 213-218. [PubMed]

43. Herbein, G. The Human Cytomegalovirus, from Oncomodulation to Oncogenesis. Viruses 2018, $10,408$. [CrossRef] [PubMed]

44. Feire, A.L.; Koss, H.; Compton, T. Cellular integrins function as entry receptors for human cytomegalovirus via a highly conserved disintegrin-like domain. Natl. Acad. Sci. 2004, 101, 15470-15475. [CrossRef] [PubMed]

45. Wang, X.; Huang, D.Y.; Huong, S.-M.; Huang, E.-S. Integrin alphavbeta3 is a coreceptor for human cytomegalovirus. Nat. Med. 2005, 11, 515-521. [CrossRef] [PubMed]

46. Falcão, A.S.C.; da Costa Vasconcelos, P.F.; Lobato da Silva, D.F.; Viana Pinheiro, J.J.; Falcão, L.F.M.; Quaresma, J.A.S. Mechanisms of human cytomegalovirus infection with a focus on epidermal growth factor receptor interactions. Rev. Med. Virol. 2017, 27, e1955. [CrossRef] [PubMed]

47. Stegmann, C.; Hochdorfer, D.; Lieber, D.; Subramanian, N.; Stöhr, D.; Sampaio, K.L.; Sinzger, C. A derivative of platelet-derived growth factor receptor alpha binds to the trimer of human cytomegalovirus and inhibits entry into fibroblasts and endothelial cells. PLoS Pathog. 2017, 13, e1006273. [CrossRef] [PubMed]

48. Martinez-Martin, N.; Marcandalli, J.; Huang, C.S.; Arthur, C.P.; Perotti, M.; Foglierini, M.; Ho, H.; Dosey, A.M.; Shriver, S.; Payandeh, J.; et al. An Unbiased Screen for Human Cytomegalovirus Identifies Neuropilin-2 as a Central Viral Receptor. Cell 2018, 174, 1158-1171. [CrossRef] [PubMed]

49. Levy, S.; Shoham, T. Protein-protein interactions in the tetraspanin web. Physiology (Bethesda) 2005, 20, 218-224. [CrossRef] [PubMed]

50. Higginbottom, A.; Takahashi, Y.; Bolling, L.; Coonrod, S.A.; White, J.M.; Partridge, L.J.; Monk, P.N. Structural requirements for the inhibitory action of the CD9 large extracellular domain in sperm/oocyte binding and fusion. Biochem. Biophys. Res. Commun. 2003, 311, 208-214. [CrossRef] [PubMed]

51. Zhang, X.A.; Kazarov, A.R.; Yang, X.; Bontrager, A.L.; Stipp, C.S.; Hemler, M.E. Function of the tetraspanin CD151- $\alpha 6 \beta 1$ integrin complex during cellular morphogenesis. Mol. Biol. Cell 2002, 13, 1-11. [CrossRef] [PubMed]

52. Lammerding, J.; Kazarov, A.R.; Huang, H.; Lee, R.T.; Hemler, M.E. Tetraspanin CD151 regulates alpha6beta1 integrin adhesion strengthening. Proc. Natl. Acad. Sci. USA 2003, 100, 7616-7621. [CrossRef] [PubMed]

53. Liu, L.; He, B.; Liu, W.M.; Zhou, D.; Cox, J.V.; Zhang, X.A. Tetraspanin CD151 promotes cell migration by regulating integrin trafficking. J. Biol. Chem. 2007, 282, 31631-31642. [CrossRef] [PubMed]

54. Baldwin, G.; Novitskaya, V.; Sadej, R.; Pochec, E.; Litynska, A.; Hartmann, C.; Williams, J.; Ashman, L.; Eble, J.A.; Berditchevski, F. Tetraspanin CD151 regulates glycosylation of $\alpha 3 \beta 1$ integrin. J. Biol. Chem. 2008, 283, 35445-35454. [CrossRef] [PubMed]

55. Taur, J.-S.; Schuck, E.L.; Wong, N.Y. A transcellular assay to assess the P-gp inhibition in early stage of drug development. Drug Metab. Lett. 2012, 6, 285-291. [CrossRef] [PubMed] 
56. Krippendorff, B.-F.; Lienau, P.; Reichel, A.; Huisinga, W. Optimizing classification of drug-drug interaction potential for CYP450 isoenzyme inhibition assays in early drug discovery. J. Biomol. Screen 2007, 12, 92-99. [CrossRef] [PubMed]

57. Heo, J.-K.; Nguyen, P.-H.; Kim, W.C.; Phuc, N.M.; Liu, K.-H. Inhibitory Effect of Selaginellins from Selaginella tamariscina (Beauv.) Spring against Cytochrome P450 and Uridine 5'-Diphosphoglucuronosyltransferase Isoforms on Human Liver Microsomes. Molecules 2017, 22, 1590. [CrossRef] [PubMed]

58. Sapp, M.; Kraus, U.; Volpers, C.; Snijders, P.J.; Walboomers, J.M.; Streeck, R.E. Analysis of type-restricted and cross-reactive epitopes on virus-like particles of human papillomavirus type 33 and in infected tissues using monoclonal antibodies to the major capsid protein. J. Gen. Virol. 1994, 75 Pt 12, 3375-3383. [CrossRef]

59. Rommel, O.; Dillner, J.; Fligge, C.; Bergsdorf, C.; Wang, X.; Selinka, H.C.; Sapp, M. Heparan sulfate proteoglycans interact exclusively with conformationally intact HPV L1 assemblies: Basis for a virus-like particle ELISA. J. Med. Virol. 2005, 75, 114-121. [CrossRef] [PubMed]

60. Bienkowska-Haba, M.; Patel, H.D.; Sapp, M. Target Cell Cyclophilins Facilitate Human Papillomavirus Type 16 Infection. PLoS Pathog. 2009, 5, e1000524. [CrossRef] [PubMed]

61. Ho, S.H.; Martin, F.; Higginbottom, A.; Partridge, L.J.; Parthasarathy, V.; Moseley, G.W.; Lopez, P.; Cheng-Mayer, C.; Monk, P.N. Recombinant extracellular domains of tetraspanin proteins are potent inhibitors of the infection of macrophages by human immunodeficiency virus type 1. J. Virol. 2006, 80, 6487-6496. [CrossRef] [PubMed]

62. Zhang, J.; Randall, G.; Higginbottom, A.; Monk, P.; Rice, C.M.; McKeating, J.A. CD81 is required for hepatitis C virus glycoprotein-mediated viral infection. J. Virol. 2004, 78, 1448-1455. [CrossRef] [PubMed]

63. Pileri, P.; Uematsu, Y.; Campagnoli, S.; Galli, G.; Falugi, F.; Petracca, R.; Weiner, A.J.; Houghton, M.; Rosa, D.; Grandi, G.; et al. Binding of hepatitis C. virus to CD81. Science 1998, 282, 938-941. [CrossRef] [PubMed]

64. Earnest, J.T.; Hantak, M.P.; Li, K.; McCray, P.B.; Perlman, S.; Gallagher, T. The tetraspanin CD9 facilitates MERS-coronavirus entry by scaffolding host cell receptors and proteases. PLoS Pathog. 2017, 13, e1006546. [CrossRef] [PubMed]

65. Lieber, D.; Hochdorfer, D.; Stoehr, D.; Schubert, A.; Lotfi, R.; May, T.; Wirth, D.; Sinzger, C. A permanently growing human endothelial cell line supports productive infection with human cytomegalovirus under conditional cell growth arrest. BioTechniques 2015, 59, 127-136. [CrossRef] [PubMed]

66. Buck, C.; Pastrana, D.; Lowy, D.; Schiller, J. Efficient intracellular assembly of papillomaviral vectors. J. Virol. 2004, 78, 751. [CrossRef] [PubMed]

67. Sinzger, C.; Schmidt, K.; Knapp, J.; Kahl, M.; Beck, R.; Waldman, J.; Hebart, H.; Einsele, H.; Jahn, G. Modification of human cytomegalovirus tropism through propagation in vitro is associated with changes in the viral genome. J. Gen. Virol. 1999, 80 Pt 11, 2867-2877. [CrossRef] [PubMed]

68. Volpers, C.; Unckell, F.; Schirmacher, P.; Streeck, R.E.; Sapp, M. Binding and internalization of human papillomavirus type 33 virus-like particles by eukaryotic cells. J. Virol. 1995, 69, 3258-3264. [PubMed]

69. Rocha-Perugini, V.; Suárez, H.; Álvarez, S.; López-Martín, S.; Lenzi, G.M.; Vences-Catalán, F.; Levy, S.; Kim, B.; Muñoz-Fernández, M.A.; Sánchez-Madrid, F.; et al. CD81 association with SAMHD1 enhances HIV-1 reverse transcription by increasing dNTP levels. Nat. Microbiol. 2017, 2, 1513-1522. [CrossRef] [PubMed]

70. Spoden, G.A.; Besold, K.; Krauter, S.; Plachter, B.; Hanik, N.; Kilbinger, A.F.; Lambert, C.; Florin, L. Polyethylenimine Is a Strong Inhibitor of Human Papillomavirus and Cytomegalovirus Infection. Antimicrob. Agents Chemother. 2011, 56, 75-82. [CrossRef] [PubMed]

(C) 2018 by the authors. Licensee MDPI, Basel, Switzerland. This article is an open access article distributed under the terms and conditions of the Creative Commons Attribution (CC BY) license (http://creativecommons.org/licenses/by/4.0/). 